\title{
The Role of Relationship Lending in SMEs Funding
}

\author{
Muhammad Fuad \\ \{muhammad.fuad25@gmail.com\} \\ Universitas Muhammadiyah Purwokerto
}

\begin{abstract}
The issue of SMEs funding has been widely discussed by international scholars. One important issue is the access to get funding. Many studies have too narrowly focused on the supply side of the capital. However, To look at the problem of SMEs funding deeply, a review on the demand side should be done further. On the supply side, banks have to deal with the problem of asymmetry information and agency behavior, while on the demand side, owners' control has been the issue. The owners are often found reluctant to add capital to keep their firms in their control. Finally, this review gives the main solution to this problem by promoting relationship lending to minimize the disadvantages that possibly arise in conventional loan transactions. Some steps in creating good and conducive business environment and banking system need to be done to support the idea.
\end{abstract}

Keywords: Relationship Lending; SMEs Funding, Capital Access, Funding Availability

\section{Introduction}

The topic of SMEs funding has been much discussed in literatures. This discussion has covered some factors which might influence funding decisions in SMEs and highlight the impacts on the performance and risk of SMEs. these factors possibly come from both demand, which is from the behavior of borrowers and supply side, which relates to the availability of bank loan and equity. The impact of the funding decisions would also affect the performance and risk of SME's, which eventually would also determine their growth. Therefore, the owners of SMEs are expected to understand the factors which should be considered in making the decisions to fund their business.

There have been three well-known classic theories which underlie funding decisions done by finance managers. The theories are trade-off theory, pecking order theory, and free cash flow theory [1]. Trade off theory emphasizes on optimizing the benefits of debt to increase company's value. Pecking order theory is based on the cost of capital charged to obtain the money. That is, managers tend to prioritize the source of fund at the lowest cost. Finally, free cash flow theory states that companies will tend to borrow when the company has large cash inflow but no investment opportunities can be made.

There are three sources of capital for firms, namely internal capital sources that come from the firms' cash flow and external capital sources which can be obtained in the form of debt and equity. How SME business units obtain capital sources can be reviewed in terms of demand and supply. In terms of demand, SME capital decisions are more influenced by the behavior of the owners, both from their risk preferences and from their desire to gain full control over their business units. In terms of supply, the source of capital for SMEs tends to be determined by the availability of capital from external parties, especially banks. 
One source of SMEs funding problems comes from the supply side, which is the availability of external funding sources, such as banks. Banks deal with two main problems, information asymmetry and agency costs [2]. Information asymmetry arises when banks obtain different information related to the firms' business operations. Meanwhile, agency costs arise when firms' agents, in this case are business owners, act on their own behalf to maximize their profits without considering the interests of the bank. Actually, these two problems can be mitigated by maximizing the monitoring function carried out by the bank.

However, it is, in fact, not only banks that have problems in loan transactions. SMEs also have concerns about the exploitation of private information obtained by banks [3,4]. Because loan transactions are a type of two-way interaction, the process of transferring information and knowledge takes place in this relationship. On the one hand, banks can act as a source of information about industries and competitions that are useful for a firm [5-7]. On the other hand, banks can also act as disseminators of valuable private information for other firms. These problems sometimes make the availability of SMEs funding sources limited, slowing the SMEs' growth $[8,9]$.

Another problem of SME's funding is caused by the lack of demand or the behavior of business owners who are reluctant to make funding decisions due to several factors [2] Hutchinson (1995) [2] stated that risk preferences and motivation to control a firm often underlie the behavior of owners in making funding decisions. SMEs owners who have a preference for avoiding risk and maintaining control of their firm tend to use relatively low capital expenditure, so they are reluctant to increase their capital. Therefore, even though external funding sources are available, they are not interested in taking the opportunity to invest.

The problems discussed above leads to the core problem of SMEs that are likely to come from the level of information openness between the parties involved. The majority of SMEs are relatively small, which comprise a lot of soft information so that it is difficult for other parties to calculate growth opportunities and risks that might be faced in the future. Therefore, Saparito, Chen, \& Sapienza (2004) [10] promoted the relationship between firms and banks in lending transactions based more on trust from both parties. The lending can be categorized as transactional, i.e. lending transactions based on physical information, or relational in nature, i.e. lending transactions based on soft information. The trust grows in the type of relational lending because bank-firm interaction much relies on soft information which will be very difficult to measure. Thus, the transaction will only occur if there is trust from both parties.

The potential benefits gained when making relationship lending have been widely discussed in the literature $[3,11,12]$. This literature review will discuss in more detail the problems that arise in SMEs funding and how solutions can be provided given the benefits of relationship lending.

\section{Method}

\section{The Problem Of Smes Funding}

The availability of capital is very important for a firm. Easy access to capital is a determining factor for the growth of a firm, especially small-scale firms [8]. Often, small firms miss investment opportunities that have the potential to make the firms grow large simply because there is no sufficient source of capital. not only that, another funding problem can also come from the reluctance of business owners to increase capital due to several considerations. 
Thus, the demand for capital is directly influenced by the objectives of the owner and their level of risk preference and is indirectly affected by equity considerations [2].

Many literatures have discussed the problem of SMEs funding originated from the supply side $[3,12,13]$. Banks have the potential to face the problem of information asymmetry when providing loans to small-scale firms. Small firms tend to have low levels of transparency making it difficult for banks to estimate the level of risk and potential growth of these firms. If the bank only relies on soft information, there is a chance that the bank will face selection problem and result in the effectiveness of the bank's debt portfolio performance [14]. In addition, there is a tendency that small firms prioritize investment in intangible assets, which is one step to achieve operational flexibility. This condition makes it increasingly difficult for banks to measure the feasibility of firms to get loans.

Another form of SMEs funding problem is agency cost. Agency problems arise when an agent, which is a firm representation, acts only based on his own interests and sometimes ignores the interests of other parties, such as banks. The agency cost is closely related to information asymmetry. As compensation for the high risk, banks often charge high capital cost to firms. This situation provides incentives for firms to make investment decisions that tend to be risky, so that they are able to get profits that can be used to pay capital cost [15].

In the case of information asymmetry and agency costs, bank is the one which is likely to get the drawbacks. It is because when a firm which make high-risk investment succeed, the profit shared to banks still remains the same. However, if the firm fails, the bank will have to accept risk of default. This is one of the reasons why the supply of external capital is limited. Basically, banks still have the ability to mitigate this risk by developing sophisticated instruments to assess creditworthiness of a firm [16]. The existence of large legal financial institutions with a sophisticated system contributes to the growth of SMEs in a country because such institutions are able to develop a system to properly assess creditworthiness $[8,9]$.

One of the instruments commonly used by banks is asset collateral [16]. Banks generally require a loan guarantee in the form of tangible assets that can be measured clearly and adjusted to the amount of the loan. However, sometimes many SMEs owners do not have enough assets to collateralize. In addition, the characteristics of SMEs tend to be more dependent on intangible assets, making it difficult to assess their feasibility accurately. This condition becomes a barrier for SMEs to get funding from banks.

While the majority of studies in lending literature focus more on the supply side, the problem of SMEs funding which comes from the demand side also need to get more attention [2]. The risk preferences of the owners and operational control of SMEs are factors that affect the willingness of SMEs owners to increase their external capital. Because SME owners have a desire to make their firms remain in control, they tend to avoid funding through equity. In addition, the source of the equity fund itself is generally sourced from friends or family of the owners, thus allowing for a subjective assessment of the business operations. Therefore, the reluctance of SMEs owners to obtain sources of equity funds causes the tendency for SMEs to depend more on debt. Some SMEs are even willing to accept the conditions of insufficient capital to be able to maintain full control over their firms.

The dependence of SMEs on banks affects the investment behavior of SMEs owners [2]. As compensation for the inherent risk when giving loans to SMEs, banks impose high capital cost. There are two possible responses done by SMEs owners. First, because they are charged with high capital cost, SMEs owners are encouraged to make relatively risky investment decisions in the hope of getting high returns [14,15]. With high risk, the probability of success of SMEs business operations becomes relatively smaller than when investing at low risk. The 
consequence of this situation is the possibility of not creating a good and mutually beneficial business relationship [14].

The second response taken by SMES owners is to maintain the trust of banks to reduce the cost of capital that may be charged by investing at a low level of risk. Because of the tendency to rely on banks and the desire to be able to reduce the cost of capital, SMEs owners make low-risk investment decisions to ensure that there is a commitment to conduct business transactions that are profitable for banks $[11,13]$. However, this situation does not also mean that it has no negative influence on SMEs business operations. The reason is, when SMEs owners tend to impose relatively non-aggressive investment policies, the growth of their firms is likely to slow down, and, even worse, will stop and remain at the same business level for a long period of time.

\section{Result And Discussion}

\subsection{The Benefits Of Relationship Lending}

Several studies have discussed the positive contribution of relationship lending to firms $[11,12,17,18]$. The benefits of relationship lending could be derived from capital cost $[17,18]$, the availability of capital [11], monitoring [3], and sharing of knowledge [5-7].

firms which carry out relationship lending get benefit from capital cost. The benefit of capital cost does not necessarily mean that firms get relatively cheaper capital cost, but the firms also get the sustainability of the expected capital cost. Berlin and Mester $(1998,1999)$ $[17,18]$ found that in relationship lending, banks tend to charge stable interest costs even when firms' credit risk fluctuate. this relationship also promotes both parties to be mutually beneficial, so that when one party's performance improves, the other party will also benefit from the increase, both in the current loan period and in the next period [13].

The second benefit of relationship lending is the availability of a good source of funds for firms. Rajan \& Petersen (1994) [11] revealed that the main benefits of relationship lending are not in the terms of the cost but rather in the availability of funds for firms. Banks are often concerned with the uncertainty of future profit claims when the bank is willing to help a firm by providing capital. In the first loan transaction, the bank is willing to provide funding to a developing and relatively risky firm in the hope that the bank can benefit in the future through subsequent loan transactions when the firm is growing and stable. But in reality, especially in a competitive credit competition environment, there is a threat that banks will not receive profits in the future because firms that have been given loans before have moved to make loans with other banks. This risk can be mitigated by the existence of relationship lending that are built on the basis of mutual trust. Bornheim \& Herbeck (1998) [19] also revealed that one of the benefits of relationship lending is the existence of long-term interests between banks and firms. The importance of this long-term lending transaction is also emphasized in other studies on relationship lending, for example Berlin \& Mester (1999) [18] and Schwert (2018) [12].

The third benefit of relationship lending is the benefit of monitoring. Monitoring is a mechanism where banks supervise to ensure that the operational activities of borrowing firms have carried out appropriate and rational risk management. As mentioned earlier, banks that provide loans to small firms with opaque information face problems with information asymmetry. Hutchinson (1995) [2] underlined the potential for agency behavior that is detrimental to banks. As compensation for monitoring costs and high risks, banks impose high 
interest costs and in the end, will provide an incentive for borrowers to make investments with a high level of risk and profit without rational consideration. Relationship lending based on mutual trust could mitigate the risk of agency behavior. With the desire to always maintain good relationship with banks, SMEs owners strive to provide good performance in paying debts, and with the trust of banks, banks try to provide capital cost that are relatively cheap and affordable for firms.

In addition to providing benefits to mitigate risk, monitoring done by banks also has a positive impact on firms' performance. Dass \& Massa (2011) [3] found that firms benefit from monitoring through improving corporate governance. With good corporate governance, the firm is expected to be able to improve its operational performance. Degryse \& Ongena (2001) [20] and Fok et al (2004) [21] found evidence that relationship lending affect profitability. The benefits of relationship lending on firms' performance disappear when a firm borrow from more than one bank.

The other benefit is the creation of social interaction that potentially stimulate information and knowledge transfer in two directions [5,7]. The bank has relationships with many firms in the industry. The relationship is likely to be a useful source of information and knowledge related to the mechanism of industry and competition. Therefore, it is possible that a bank could become a transmitter to transfer useful information and knowledge from one firm to another. Of course, this knowledge is still relevant and very important for a firm that receives it. The ability of banks to know the firms' business operations is also emphasized by Diamond and Rajan [22,23]. They argued that banks need to have special expertise regarding the firms' operations in order to be able to provide liquidity for firms and depositors. Without this special expertise, banks are likely to fail in carrying out their functions as an intermediary role. So, in carrying out the monitoring function, banks might also play a role and provide positive input to the firms to develop its business.

\subsection{Alternative Funding Solution For Smes}

It is undeniable that SMEs have unfavorable characteristics. That is, they mostly have low level of information transparency, poor corporate governance, the lack of assets that can be used for collateral, and the lack of professionalism of the SMEs owners itself. All of these weaknesses are the reasons why SMEs seem not to get adequate source of funding to run their business operations well. Therefore, it is necessary to have synergy and integrity for all stakeholders, such as businessmen, banks, and the government as regulators, in order to advance the industry and create a good business environment.

What will happen if all stakeholders pay less attention to this issue is certainly not a difficult question to answer. First, both banks and firms act to maximize their own benefit. If this happens, banks will only provide loans to profitable SMEs, leaving more opaque and less transparent SMEs at the risk of getting less access to funding from banks. Even if banks are willing to give loans to these SMEs, banks are more likely to charge high interest cost as risk compensation $[4,12]$. This situation will encourage SMEs owners to take risky investment, and if they fail, this situation will continue to recur and create unstable economic conditions [14]. Second, if the government does not act as a good regulator, there will be no regulation that supports industries [14] and eventually slow down the banking system which is crucial for the growth of SMEs $[8,9]$.

The answer to this problem is creating a good business relationship between banks and firms [24]. Relationship lending provide many benefits for both firms and banks. High monitoring costs can be reduced when banks and firms commit to having a good long-term relationship. Through long and continuous interaction, banks and firms will both understand 
each other's business mechanisms so that they take mutually supportive decisions. A good monitoring system and mutual trust between two parties alleviate information asymmetry thereby reducing banks' concerns about uncertainty and risk. Thus, banks are willing to provide capital cost that are affordable and help firms to improve their business performance for the sake of both parties [3,20,21].

From the perspective of the firms, relationship lending becomes a good alternative funding which is accessible and sustainable for them $[11,13]$. SMEs no longer need to miss profitable investment opportunities that potentially help them scale up their their business operations. Although some literature found that the firms' dependence on banks has a negative impact on the firms because of information monopolies [4,12], relationship lending could mitigate this risk. When the two parties are related and trust each other, any possible behavior that harms one of the parties will have little chance to occur. The exchange of information between them also minimizes the possibility of information monopolies.

The role of government is also needed to create good business relationship. Banks and firms that meet and do business transaction often have matching characteristics. A risky matching is when both institutions share poor performance and risk [12,14,25]. This kind of poor matching are potentially failed in their business that will damage the business environment and the economy as a whole. The government could take a preventive step by creating strict and systematic banking regulations. In addition to regulation, the government could also encourage the creation of sophisticated banking infrastructure. Legal, measured and sophisticated banking infrastructure and system can encourage the growth of SMEs in a country $[8,9,16]$. If legal financial institutions are not able to meet the demand for funds, then what will happen is that many business units such as SMEs are competing to get financial source, which of course with a high level of capital cost. Therefore, this high capital cost will hamper SMEs growth and perhaps the worst condition will destroy SMEs businesses.

\section{Conclusion}

The issue of SMEs funding has been widely discussed by international scholars. One of the problems is the supply side, where many banks face difficulties when dealing with business units such as SMEs. Not only that, SMEs owners are sometimes reluctant to add funds due to risk preference and firms' control. However, relationship lending is a form of loan transaction that can be used to address this problem.

Still at the supply, banks often face the problem of information asymmetry and agency behavior. As is well known, the SMEs have less transparent and opaque information, making it difficult for banks to measure risk and monitor the performance of their loan portfolios. As compensation for this risk, banks are willing to provide loans but with high capital cost. As a result, a second problem arises, called agency cost. That is, the SMEs owners act in his own interest by making risky investment in order to get high returns. In fact, this situation can be mitigated by using asset collateral. However, many SMEs have limited assets to be used as collateral for their debts. And moreover, the fact is that many developing SMEs rely more on intangible assets than tangible assets. This makes it more difficult for banks to measure the level of loan risk.

On the demand side, SMEs owners who choose to avoid risk and take full control are sometimes reluctant to increase capital despite the shortage. In order to take full control of the company, SME owners are reluctant to add capital through equity because it will reduce their 
control rights over the company. This situation increases the ratio of debt to equity which will certainly increase the credit risk of SMEs. Therefore, banks that provide loans to firms, in general, will charge relatively high interest. In order not to be burdened with higher capital costs, SMEs business owners try to reduce their credit risk by making low risk investment decisions and as much as possible and not to add debt capital to keep the debt to equity ratio low. As a result, the demand for capital in the market also declines.

The synergy and integrity of all stakeholders can be used as a solution to overcome this problem. A good relationship lending between banks and firms provides positive output for both. Relationship lending are believed to reduce the risk of information asymmetry and agency behavior. Relationship lending also provides adequate sources of funding for firms with cost that are relatively cheap and affordable for SMEs. The government role as a regulator is also needed to make regulations that encourage the creation of a conducive environment and legal, measurable and sophisticated banking system. Ultimately, a supportive environment and a synergy between parties will produce healthy and constructive business relationships that will accelerate overall economic growth. 


\section{References}

[1] Brigham EF, Ehrhardt MC. Financial Management - Theory and Practice 14th Edition. Cengage Learning; 2014.

[2] Hutchinson RW. The Capital Structure and Investment Decisions of the Small Owner-Managed Firm: Some Exploratory Issues The Capital Structure and Investment Decisions of the Small Owner-Managed Firm : Some Exploratory Issues. Small Bus Econ 1995;7:231-9.

[3] Dass N, Massa M. The impact of a strong bank-firm relationship on the borrowing firm. Rev Financ Stud 2011;24:1204-60. https://doi.org/10.1093/rfs/hhp074.

[4] Santos JAC, Winton A. Bank Loans , Bonds , and Information Monopolies across the Business Cycle Published by: Wiley for the American Finance Association Bank Loans, Bonds, and Information Monopolies across the Business Cycle 2016;63:1315-59.

[5] Uzzi B. Embeddedness in the Making of Financial Capital : How Social Relations and Networks Benefit Firms Seeking Financing Author ( s ): Brian Uzzi Source: American Sociological Review , Vol . 64 , No . 4 ( Aug ., 1999 ), pp . 481-505 Published by: American So 1999;64:481-505.

[6] Uzzi B, Gillespie J. Corporate social capital and the cost of financial capital: an embeddedness approach. Corp Soc Cap 1999:385-98.

[7] Uzzi B, Gillespie JJ. Knowledge spillover in corporate financing networks: Embeddedness and the firm's debt performance. Strateg Manag J 2002;23:595-618. https://doi.org/10.1002/smj.241.

[8] Beck T, Demirguc-Kunt A. Small and medium-size enterprises: Access to finance as a growth constraint. J Bank Financ 2006;30:2931-43. https://doi.org/10.1016/j.jbankfin.2006.05.009.

[9] Beck T, Demirgüç-Kunt A, Maksimovic V. The influence of financial and legal institutions on firm size. J Bank Financ 2006;30:2995-3015. https://doi.org/10.1016/j.jbankfin.2006.05.006.

[10] Saparito PA, Chen CC, Sapienza HJ. The Role of Relational Trust in Bank-Small Firm Relationships Author ( s ): Patrick A . Saparito, Chao C . Chen and Harry J . Sapienza Published by: Academy of Management Stable URL: https://www.jstor.org/stable/20159589 REFERENCES Linked references ar 2004;47:400-10.

[11] Rajan RG, Petersen MA. American Finance Association The Benefits of Lending Relationships : Evidence from Small Business Data Author ( s ): Mitchell A . Petersen and Raghuram G . Rajan Source: The Journal of Finance, Vol . 49 , No . 1 ( Mar ., 1994 ), pp . 3-37 Published by: J Finance 1994;49:3-37.

[12] Schwert M. Bank Capital and Lending Relationships. J Finance 2018;LXXIII:787-830. https://doi.org/10.1111/jofi.12604.

[13] Petersen MA, Rajan RG. The Effect of Credit Market Competition on Lending Relationships. Q J Econ 1995;110:407-43.

[14] Peek J, Rosengren ES. Unnatural Selection: Perverse Incentives and the Misallocation of Credit in Japan. Am Econ Rev 2005;95:1144-66.

[15] Stiglitz BJE, Weiss A. Credit Rationing in Markets with Imperfect Information. Am Econ Assoc 1981;71:393-410.

[16] Berger AN, Udell GF. A more complete conceptual framework for SME finance. J Bank Financ 2006;30:2945-66. https://doi.org/10.1016/j.jbankfin.2006.05.008.

[17] Berlin M, Mester LJ. On the profitability and cost of relationship lending. J Bank Financ 1998;22:873-97. https://doi.org/10.1016/S0378-4266(98)00033-8.

[18] Berlin M, Mester LJ. Deposits and relationship lending. Rev Financ Stud 1999;12:579-607. https://doi.org/10.1093/revfin/12.3.0579.

[19] Bornheim SP, Herbeck TH. A Research Note on the Theory of SME - Bank Relationships. Small Bus Econ 1998;10:327-31. https://doi.org/10.1023/A:1007907427042.

[20] Degryse H, Ongena S. Bank relationships and firm profitability. Financ Manag 2001;30:9-34. https://doi.org/10.2307/3666389.

[21] Fok RCW, Chang Y, Lee W, Fok RCW, Chang Y, Lee W. Bank Relationships and Their Effects on Firm Performance around the Asian Financial Crisis : Evidence from Taiwan. Financ Manag 2004;33:89-112. 
[22] Diamond DW, Rajan RG. A Theory of Bank Capital. J Finance 2000;55:2431-65.

[23] Diamond DW, Rajan RG. Banks and Liquidity. Am Econ Rev 2001;91:422-5.

[24] Berger AN, Udell GF. Small business credit availability and relationship lending: The importance of bank organisational structure. Econ J 2002;112:F32-53. https://doi.org/10.1111/1468-0297.00682.

[25] Iosifidi M, Kokas S. Who lends to riskier and lower-profitability firms? Evidence from the syndicated loan market. J Bank Financ 2015;61:S14-21. https://doi.org/10.1016/j.jbankfin.2015.02.008. 